\title{
Az ultrahang-képalkotás alkalmazása biotechnikai előrelépés a perioperatív fájdalomcsillapításban
}

\author{
Almási Róbert Gyula dr. \\ Pécsi Tudományegyetem, Általános Orvostudományi Kar, Klinikai Központ, Janus Pannonius Klinikai Tömb, \\ Aneszteziológiai és Intenzív Terápiás Intézet, Fájdalomterápiás Tanszék, Pécs
}

\begin{abstract}
A perioperatív fájdalom - az eddigi erőfeszítések, irányelvek és protokollok ellenére - alulértékelt és alulkezelt. A sebészi bemetszés okozta inzultus altatott beteg esetén is nociceptiv ingerek tömegével árasztja el az idegrendszert. Ezek feldolgozása során stressz és modulációs mechanizmusok váltódnak ki, melyek jelentősen befolyásolhatják a kimenetelt. A műtőből kiadott betegeknél az első rendelések után a fájdalomcsillapítás menete megszakad, a betegek többsége fájdalomról panaszkodik. A regionális anesztézia koncepcionálisan megakadályozza a káros ingerek központi idegrendszerbe jutását, így - a mútéti érzéstelenítés mellett - alkalmas lehet a közvetlen mútét utáni időszak fájdalmainak csillapítására is. Releváns irodalmi adatok alapján bemutatjuk a regionális anesztézia történetét, a fájdalomcsillapítás multidimenzionális modelljében betöltött szerepét. A perioperatív fájdalom kórélettanában az elhúzódó nociceptiv ingerek okozta túlérzékenyítődés - perifériás és centrális szenzitizáció, leszálló moduláció - mellett számos biopszichoszociális faktor is felmerül. Az általános érzéstelenítés potenciális mellékhatásainak kivédése mellett az ultrahang-irányítással végzett perifériás idegblokád biztonságos, találati pontossága magas, a szövődmény kevés, a fájdalomcsillapítás kitűnő, hosszan tartó. Ultrahang segítségével behelyezett perineuralis katéterrel a fájdalomkontroll kiterjeszthető. A perifériás idegblokád a multimodális analgesia részeként kivédi a centrális szenzitizációt. A regionális érzéstelenítésben operált betegek mútét utáni fájdalma kisebb intenzitású, a krónikus tendencia csökken, az életminőség és a betegkomfort javul, a stresszválasz gyengül, a betegek nagy része mentesül az általános érzéstelenítés nemkívánatos szövődményeitől, mellékhatásaitól. A ma már egyre növekvő számban mútét előtt alkalmazott perifériás idegblokád bizonyítottan hatékony eszköz a krónikus posztoperatív fájdalom megelőzésében. Ultrahang-irányítással nemcsak mútéti érzéstelenítés, de hosszan tartó fájdalomcsillapítás is végezhetô, melyek elérése a gazdasági tényezők mellett betegeink érdekét is célozza.
\end{abstract}

Orv Hetil. 2019; 160(15): 573-584.

Kulcsszavak: regionális anesztézia, fájdalomcsillapítás, idegblokád

\section{Ultrasound imaging has a potential to exhibit biotechnical advance in perioperative pain management}

The perioperative pain management - instead of the efforts, guidelines and protocols - is underestimated and undertreated. Even in the case of general anaesthesia, the nervous system is overwhelmed by copious quantities of nociceptive stimuli at surgical incision. Stress and pain-modulation processes are triggered which can have significant influence on the outcome. Often the pain-management is discontinued, so a notable part of patients complain about pain in the ward after surgery. Regional anaesthesia conceptually prevents noxious inputs to enter the central nervous system, beyond surgical anaesthesia it is pertinent to achieve excellent analgesia in the immediate postoperative period as well. Based on current literature, this paper provides an overview of the history and role of regional anaesthesia in the multidimensional model of pain. Besides the sensitization caused by nociceptive stimuli - peripheral and central sensitization, descending modulation - there are several biopsychosocial factors involved in pain pathophysiology. Preventing the side effects of general anaesthesia, the ultrasound-guided peripheral nerve blockade is a safe technique with high success rate, rare side effects, achieving long-lasting, excellent analgesia. Continuous perineural catheter placed under ultrasound provides extended pain control. As a part of multimodal analgesia, peripheral nerve blockade prevents central sensitization. After surgery, the pain intensity of patients under peripheral nerve blockade is less, the chronification tendency is decreased, the quality of life and patients' comfort are improved, and the stressresponse is attenuated. The greater part of patients are protected from the undesirable side effects of general anaesthesia. Nowadays, it is an unequivocal evidence that the increasingly used peripheral nerve blockades prior to incision 
are efficient tools in the prevention of chronic postoperative pain. Ultrasound guidance is suitable not only for surgical anaesthesia, but for postoperative pain management as well, however, besides economic factors, the main goal of this technique is to match the best interest of the patients.

Keywords: regional anaesthesia, pain management, nerve blockade

Almási RGy. [Ultrasound imaging has a potential to exhibit biotechnical advance in perioperative pain management]. Orv Hetil. 2019; 160(15): 573-584.

(Beérkezett: 2018. december 3.; elfogadva: 2019. január 8.)

A Szerkesztőség felkérésére készült tanulmány.

\section{Rövidítések}

AMPA = (aminomethyl propanoic acid $)$ amino-metil-propánsav; $\mathrm{ATP}=$ (adenosine triphosphate) adenozin-trifoszfát; CGRP $=$ (calcitonin gene-related peptide) kalcitonin gén-rokon peptid; $\mathrm{COPD}=$ (chronic obstructive pulmonary disease $)$ idült obstruktív tüdőbetegség; $\mathrm{CPOP}=($ chronic postoperative pain) krónikus posztoperatív fájdalom; CPSP $=$ (chronic postsurgical pain) sebészeti beavatkozást követő krónikus fájdalom; DRG $=$ (dorsal root ganglion $)$ hátsó gyöki ganglion; EDA = (epidural anesthesia) epiduralis érzéstelenítés; FIB = femoralis idegblokád; GA = (general anaesthesia) általános érzéstelenítés; IASP $=($ International Association for the Study of Pain $)$ Nemzetközi Fájdalom Kutató Társaság; ISC = interscalenicus; LA = (local anesthetic) helyi érzéstelenítő; LAST $=($ local anaesthetic systemic toxicity) helyi érzéstelenítő szisztémás toxicitása; LTD $=$ (long-term depression) hosszan tartó depresszió; LTP = (long-term potentiation) hosszú idejü erôsítés; NK = (natural killer $)$ természetes ölősejt; NMDA $=(\mathrm{N}$-methyl-D-aspartic acid) N-metil-D-aszparaginsav; NSAID $=$ (nonsteroidal antiinflammatory drug) nemszteroid gyulladáscsökkentő; $\mathrm{PBB}=$ plexus brachialis blokád; PCA $=$ (patient-controlled analgesia $)$ pácienskontrollált analgesia; $\mathrm{PIB}=$ perifériás idegblokád; $\mathrm{PKD}$ $=$ (postoperative cognitive dysfunction) posztoperatív kognitív diszfunkció; POP = (postoperative pain) mútét utáni fájdalom; $\mathrm{QL}=$ quadratus lumborum; $\mathrm{RA}=$ (regional anaesthesia) regionális érzéstelenítés; $S A=$ (spinal anaesthesia) gerincérzéstelenítés; $\mathrm{sP}=($ substance $\mathrm{P}) \mathrm{P}$-anyag; $\mathrm{STD}=$ (short-term depression) rövid ideig tartó depresszió; $\mathrm{STF}=$ (short-term facilitation) rövid idejű folyamat; TAP $=$ (transversus abdominis plane) haránt hasizom rétegblokád; TND $=$ (transient neurologic deficit) átmeneti neurológiai deficit; $\mathrm{UH}=$ ultrahang; VNS = vizuális numerikus skála; WDR = (wide dynamic range $)$ széles dinamikus tartományú

A mútéti és a mútétet követó fájdalom nagy kihívást jelentett és jelent ma is a betegek és az ellátószemélyzet számára. A korabeli középkori technikák, az alkohol, az ópium használata jelentőségüket vesztették az általános érzéstelenítés (general anesthesia - GA) bemutatásával (Boston, 1846. október 16.), ám hamarosan újabb problémával kellett szembesülniük az akkori sebészeknek: monitorozás és biztonságos lélegeztetés hiányában egyre több haláleset fordult elő [1]. Az éber állapotban végzett operációk biztonságosabbnak túntek, emiatt a regionális érzéstelenítés (regional anesthesia - RA) megkezdte hódító útját.

\section{Történeti áttekintés}

A korabeli sebészek és az érzéstelenítésre fókuszáló orvosok már felfigyeltek a regionális anesztéziában rejlő lehetőségekre, főként a spinalis és az epiduralis érzéstelenítésre, melyektól nagyobb biztonságot reméltek. A kokacserjéből egy eritroxilinnek nevezett [2], érzéstelenítő hatású anyagot izoláltak (Gaedcke, 1855), míg Wood ugyanebben az évben kifejlesztette a fecskendőt, megteremtve az injekciós érzéstelenítés alapját. A kokain hatásáról Montegazza közölte az első részletes leírást 1857 ben. Az első kokainos érzéstelenítést 30 év múlva egy bécsi szemész, Koller végezte (1884) [3], majd Corning New York-i ideggyógyász spinalis érzéstelenítéshez használta a kokaint [4], ám az első epiduralis érzéstelenítést (EDA) sikerült megvalósítania [5]. A durapunkciót Essex Wynter, majd 6 hónappal később Heinrich Quincke közölte. Egy kieli német sebész, Bier (1898), sikeres önkísérletek során tett megfigyeléseket a spinalis anesztézia (SA) alkalmazásáról. A karfonat (plexus brachialis) blokádját (PBB) kokain direkt injektálásával egy amerikai sebész, Halsted alkalmazta először (1884) [6], majd Hirschel és Kulenkampff leírta az első percutan technikát (1911) az axillaris és supraclavicularis megközelítésre [7, 8]. A pneumothorax kivédésére áttértek az interscalenicus (ISC) módszerre (Mulley, 1919); a napjainkban is alkalmazott modern megközelítést Winnie dolgozta ki 1970-ben [9].

A lumbalis plexus blokádját, majd caudalis epiduralis kiegészítését Bogdan írta le elsőként. Az epiduralis punkció „loss-of-resistance” módszerét Dogliotti olasz sebész közölte, míg a folyamatos caudalis anesztézia technikáját Hingson és munkatársai tették közzé. Hugo Sellheim (Leipzig, 1905) elsőként végzett thoracalis paravertebralis blokádot, míg Kappis (1919) nevéhez a mai értelemben is használatos paravertebralis injekció módszerének leírása füződik. Eason és Wyatt a paravertebralis katéter behelyezési technikáját adták közre.

Napjainkig még számos technikai leírás, találmány, újítás és szerzői név található a RA módszereinek palettáján [10], egy azonban mint mérföldkő feltétlenül kiemelendő ezek közül: az első, ultrahang (UH)-vizsgálattal megfigyelt helyiérzéstelenítő-terjedést a brachialis plexus axillaris megközelítésénél Ting és Sivagnanarat- 
nam [11] tették közzé 1989-ben, majd 5 évvel később Kapral és mtsai közölték az első összehasonlító vizsgálatot UH segítségével végzett supraclavicularis blokáddal [12].

\section{Az általános és a regionális érzéstelenítés fejlődése}

Az 1950-es évekre az altatásos érzéstelenítés mortalitása 3,7/1000 páciens volt, mely 30 évvel később már 1/10 000 betegre csökkent. Az anesztézia biztonságának fokozásáért akkoriban is tettek kísérletet a regionális technikák elterjesztésére. Egy átmeneti élénkebb időszakot követően a RA népszerüsége csökkent, aminek hátterében a gyógyszerkémiai ipar fejlődése, az általánosan használt biztonságosabb anesztetikumok, a minimálinvazív sebészeti technikák, illetve a RA relatíve kis találati pontossága és általánosan alacsonyabb elégedettségi mutatói állhattak. Az 1980-1990-es években hazánkban is csak néhány pillére maradt a RA oktatásának és mindennapi gyakorlatának (például: Honvéd Kórház, Budapest; Hetényi Géza Kórház, Szolnok), ahol a RA hívei lelkesen alkalmazták technikáikat és adták át tapasztalataikat a szakorvosjelölteknek és szakorvoskollégáiknak. A magyar aneszteziológia egyik kiemelkedő alakja, Széll Kálmán 1982-ben az Orvosi Hetilapban foglalta össze a RA korabeli helyzetét [13].

Mára az általános érzéstelenítés becsült mortalitása 1/300 000 páciens, így a GA és a RA között nem biztonságossági szempontok alapján kell különbséget keresni [14]. A betegek posztoperatív fájdalomcsillapításának elégtelensége újabb igényeket támasztott, így a fájdalomcsillapítás, a betegkomfort és a posztoperatív szövődmények mérséklése lett a célja az újbóli reneszánszát élni kezdő RA-technikáknak, melyek népszerűsége a nagy biztonságot és magas sikerarányt garantáló UH-irányítással végzett technikáknak köszönhető.

\section{Fájdalomelméletek}

Platón (i. e. 400) szerint a fájdalom nem csak különleges érzékelési élmény, inkább érzelem, amely akkor jelenik meg, ha egy stimulus jóval erôsebb a szokásosnál. Évezredekkel később Erb (1874) intenzitáselméletében a stimulusintenzitást és a centrális összegződést vette alapul. Von Frey (1895) specificitáselméletében úgy gondolta, hogy a látáshoz és a szagláshoz hasonlóan egy különálló szenzoros rendszerrel rendelkezünk, amely fájdalmat érzékel. Strong (1895) teóriájában a fájdalmat káros behatásra adott pszichés reakciónak és kellemetlenségnek írta le. Sherrington (1906) integratív müködési elméletében 20 év kutatási munka tapasztalataként a fájdalmat az idegrendszer integratív akciójának tartotta. Goldschnei$\operatorname{der}(1920)$ elméletében indítványozta, hogy nincs elkülönült fájdalomérzékelő rendszer, a fájdalmat érzékelő receptorok osztoznak más érzetekkel, mint például a tapintás. Nafe a posztulátumában („quantitative theory of feeling”, 1929) figyelmen kívül hagyta a specializált idegvégződéseket támogató megállapításokat; a mintaelmélet szerint minden szomatikus érzetet specifikus és egyedi mintájú idegsejtkisülés okoz.

Livingstone (1943) centrális szummációs teóriájában terjesztette elő, hogy a szövetkárosító és intenzív stimuláció gerincvelői interneuronokon végződő rostokat aktivál, melyek abnormális, folyamatosan visszaverődő ingerületköröket produkálnak, önaktiváló neuronokkal. A fájdalom negyedik teóriája azt állítja (Hardy, Wolff, Goodell, 1940), hogy a fájdalom két komponensből áll, a fájdalomészlelésből (perception) és a rá adott reakcióból. Ezt a választ komplex fiziopszichológiai folyamatként írták le, mely magában foglalja a tudatos felismerést, a múltbéli tapasztalatokat, a kulturális hátteret és számos, a fájdalomészlelést befolyásoló pszichológiai faktort. Noordenbos szenzoros interakciós elmélete (1959) két rendszert ír le a fájdalom továbbításában: egy gyors és egy lassú rendszert, mely előbbi a vékony rostok ingerületvezetését gátolja, míg az utóbbi szomatikus és visceralis afferentatiót szállít [15].

A fájdalomkutatással foglalkozó tudósok által közölt elméletek között a legnépszerúbb az 1965-ben Ronald Melzack és Patrick Wall által megalkotott kapukontroll(,gate control”) teória. A vékony fájdalomrostok aktivitása nyitja, míg a vastagabb - ártalmatlan ingereket (például tapintás, dörzsölés, enyhe nyomás) szállító - rostok aktivitása zárja a kaput. Az agyból leszálló információ vagy nyitja, vagy zárja a kaput. Az előző elméletek továbbgondolása alapján az érzékelés, a fájdalomérzet megjelenése folyamatos dinamikus integráción és moduláción megy végbe. Nézetük szerint elválik a perifériás nociceptio és az agyi fájdalompercepció: a periférián nociceptio van, a fájdalomérzékelés valójában corticalis tevékenység, így pszichológiai jelenség [16]. Elképzelésüket 1991-ben módosították, létrehozva a fájdalom neuromátrixkoncepcióját, melyben az agykérget jelölték meg a számos befutó impulzus és kifelé adott válaszreakció fó integratív központjának [17]. Elméletük alapján a fájdalom kiváltásáért nem tisztán a szenzoros afferentatio felelős, a fájdalmat hangulati, agykérgi, tudatos, kulturális, memóriaemlékek is kiválthatják és módosíthatják, továbbá a fájdalompercepció nemcsak fájdalomelkerülő magatartást vált ki, hanem érzelmi, autonóm idegrendszeri, stressz-, hormonális, immunrendszeri választ is okoz [18]. Bár a későbbi kísérletek és klinikai adatok azt mutatták, hogy a kapukontroll-teória a részleteiben nem egészen korrekt, de a modell tisztasága és a vele kapcsolatos általános képzet megváltoztatta gondolkodásunkat a fájdalommechanizmus megértésében [19]. A fájdalom elméleti megfontolásai lassanként bekerültek a napi gyakorlatba. Az 1980-as évek végén megjelent a fájdalom megelőzésének koncepciója (Wall, 1988), a preemptí analgesia fogalmát - mely az 1990-es évektől teret nyert a műtéti anesztéziában - csak később tisztázták [20]. 1998-tól kezdetét vette a fájdalom és a fájdalomcsillapí- 
tás multimodális megközelitésének koncepciója [21], mely multimodalitás vonatkozik a használt gyógyszerek támadáspontjára, az alkalmazott technikákra és a kezelésbe vont diszciplínákra egyaránt. Ezzel a folyamattal párhuzamosan a pszichológiai megközelítése mellett [22] megkezdődött a fájdalom pszichoszociális faktorainak rendszerszintű elemzése [23], mely napjainkra a fájdalom biopszichoszociális modelljében csúcsosodott ki [24]. A fájdalom nem egyszerúen idegélettani fogalom, hanem multidimenzionális jelenség, emiatt a fájdalom értékelése és kezelése is multimodális. Ezekben a fájdalommodellekben közös vonás - attól függetlenül, hogy korszerúek vagy idejétmúltak -, hogy az egyszerü nociceptiv fájdalom vagy a krónikus tendenciát mutató komplex, szociokulturális környezetre is kiható fájdalom kialakulásához intenzív szövetkárosító ingerre van szükség.

A mütéti fájdalmak krónikussá válásának tendenciáját jelentős mértékben sikerült megfékezni RA-technikák alkalmazásával, ez vezetett annak felismeréséhez, hogy a mútét utáni krónikus fájdalmak megelőzhetők. Újabb szemléletváltás kezdődött, így a preemptív analgesia helyét lassan átvette a preventív analgesia fogalma [25-28], mely a 2010-es évek második felében már széles körben elterjedt. Ma a multimodális analgesia része az elsősorban nem opioid analgetikumok párhuzamos használata, az additív vagy szinergista hatások kiaknázása, ami magasabb szintű fájdalomcsillapítást tesz lehetővé az opioidok és opioid-mellékhatások csökkentése mellett [29, 30]. Továbbá a multimodális analgesia részeként RA javasolt, amennyiben a beteg és a mütét típusa azt megengedi [31].

\section{A mútéti utáni fájdalom problémája}

A korábbi évtizedekben számos próbálkozás történt a legkülönbözőbb fájdalomcsillapítókkal, nemszteroid gyulladáscsökkentőkkel (NSAID) és opioidokkal a mütéti fájdalom enyhítésére, megelőzésére vagy kivédésére. A gyakorlat nem igazolta a kísérletes eredményekre épített elképzelést, a perioperatív fájdalom továbbra is előtérben álló probléma maradt. A mútéti fájdalom alulértékelt és alulkezelt, pedig az evidenciák száma egyre nő: a perioperatív fájdalom nagymértékben kihat a kimenetelre [32]. Több millió műtétet végeznek világszerte, és szinte minden esetben kialakul posztoperatív fájdalom (POP), amely vagy megszünik, vagy átalakul egy közel terápiarezisztens fájdalommá (chronic postoperative pain - CPOP; chronic postsurgical pain - CPSP), melynek prevalenciája $10-50 \%$, és minden $10-50$ betegből legalább egynél súlyos fájdalom áll fenn $[33,34]$. Bár a mütéttípusok, a demográfiai paraméterek, alapbetegségek rendkívül eltérőek, és a standardizálás nehézkes, az újabb szisztémás vizsgálatok mégis hasonló adatokat mutatnak. A kimenetel gyakran kétségbeejtő az egyébként sikeres sebészi beavatkozás ellenére. Az egyénre nézve stresszválasz kialakulása, kedvezőtlen neuroendokrin, metabolikus, immunológiai és hematológiai vál- tozások miatt a gyógyulási folyamat elhúzódása és további komorbiditás a potenciális következmény. Az ellátó oldaláról megnyúlik a lábadozási periódus, ami újabb eróforrás-átcsoportosítást igényel, a további diagnosztikai és terápiás ráfordítások pedig pluszterhet jelentenek. A humánerőforrás tartósan elégtelen, az ápolószemélyzet részérôl a betegre fordított idő nem növekszik. Az opioidok alkalmazása nemkívánatos szövődményekkel járhat, és a fájdalomértékelés során a tompított tudatú betegek által adott válaszok nem megbízhatók, nem tükrözik a valós intenzitásértékeket. A betegek kevésbé tudnak segítséget kérni, a nővéri munkaráfordítás számukra nagyobb, és az áttörő fájdalmakkal gyakran nem tudnak mit kezdeni. A szociális hatások között munkahelyvesztés, improduktivitás, táppénz, a családi, szociális kapcsolatok lazulása, a fizikai igénybevétel csökkenése miatti izomzatgyengülés, myofascicularis fájdalom komponens, pszichés tényezők megjelenése, depresszió, az életminőség globális romlása lehet a következménye a kialakult krónikus fájdalomnak [35, 36]. A legmagasabb incidencia a végtag-amputáció, mellkas- és szívsebészeti beavatkozások, emlőmútétek után jelentkezik. A CPSP a definíciója szerint sebészeti beavatkozást követően alakul ki, legalább 3 hónapig tart, és jelentősen befolyásolja az életminőséget; folytatása lehet az akut POP-nak, vagy tünetmentes időszak után alakul ki. Többnyire a mütéti területre lokalizálódik, de lehet kisugárzó fájdalom is. Kizárólagos kategória, mivel a fájdalom bármilyen más oka (infekció, viszszatérő rosszindulatú betegség és a megelőző fájdalmak) kizárható [37, 38].

Az IASP (Nemzetközi Fájdalom Kutató Társaság International Association for the Study of Pain) a krónikus fájdalmat biológiai érték nélküli fájdalomként definiálja. A Társaság számos próbálkozása ellenére - algoritmusok a fájdalom mérésére, irányelvek, protokollok, frissítések, előadások, továbbképzések, a nemzeti fájdalomtársaságok bevonása - megfigyelésük szerint a nemzetközi gyakorlat nem változik jelentősen.

\section{A mütéttel járó fájdalom természete}

A perioperatív fájdalom általában akut jellegű, mütéthez köthető; az incidencia meglepően magas, még aránylag kis és szokásos sebészeti beavatkozások után is. Számos esetben azonban a mútétre egy krónikus fájdalmas periódust követően kerül sor (például érsebészet - amputáció, ortopédia - protézisbeültetés). Ezeknek a fájdalmaknak már krónikus jellegük vagy neuropátiás karakterük van, mire a beteg mútétre kerül. Az alapbetegséget a beavatkozás megoldja, de az operáció utáni fájdalmas időszak kedvez a fájdalmak további fennállásának, krónikussá válásának. A krónikus mozgásszervi fájdalmakban szenvedőkből a fájdalomelkerülő magatartás sajátos antalgiás tartást és mozgásmintát vált ki, amely kíméli a károsodott ízületet, végtagot, de a medencét és a gerincet, valamint az ellenoldali végtagot tovább terheli, így az 
ezek szekunder károsodásából eredő krónikus fájdalmakat a mütét nem szünteti meg. Mütét során az ártalmas és nem károsító stimulusok óriási tömegben kerülnek a hátsó gyöki ganglionon (DRG) keresztül a gerincvelői hátsó szarvba, majd a magasabb idegrendszeri struktúrákhoz. A bejutott inger mennyisége arányos a stimulus frekvenciájával, az intenzitással és az időtartammal. Minden modalitással találkozunk: mechanikai (például tapintás, nyomás, szúrás, metszés, vágás, szakítás, húzás, feszítés, csavarás, kiízesítés, vibráció, fúrás, ütés, szegezés, csavarozás, fürészelés), termális (hideg, meleg, forró, égető), kémiai ingerek (például dezinficiensek, antibiotikumok, szövetragasztók, gyógyszerek, valamint a vértelenség által kiváltott hypoxia és acidózis, továbbá a következményes endothel- és szöveti reakciók során felszabadult szövetaktív metabolitok, szabad gyökök és mediátorok). A nem kellő mértékben és elégtelen ideig csillapított fájdalom következtében az idegrendszer integritása károsodik, és a fájdalomérzet hosszú időn keresztül fennállhat a károsító behatás megszünése után is. A szervezet fájdalomra adott reakciója ebben az esetben már sokszor károsabb, mint maga a primer behatás. Mivel nem mindenkinél alakul ki, a közlemények szerzőit zömmel a CPSP molekuláris, celluláris alapjai, az idegrendszer kóros múködése, pszichés, szociokulturális faktorok és egyéb tényezők foglalkoztatták [39]. A perzisztáló posztoperatív fájdalmat előre jelző tényezók között találunk mütét előtt fennálló faktorokat (például megelőző fájdalom, korábbi műtéti kellemetlenség, reoperáció, pszichológiai érzékenység) és sebészi beavatkozáshoz, illetve beteghez köthető faktorokat. A beavatkozásfüggö faktorok közé tartozik a mútét neme, időtartama, invazivitása, mútéti idegsérülés, a mütéti környezeti faktorok. Lényeges tényező a megfelelően megválasztott és kivitelezett anesztézia - volt-e RA? - és a perioperatív fájdalomcsillapítás tartama és minősége, a gyógyszeres kezelés multimodalitása. A beavatkozás utáni faktorok közé tartozik a megfelelő fájdalommenedzsment mellett a kemoterápiás, radioterápiás kezelés, a depresszió és a pszichológiai sérülékenység is.

A betegfüggó faktorok között az első helyen a preoperativ stressz áll, mely érzékenyíti a beteget krónikusfájdalom-szindróma kialakulására. Ez a körülmény felhívja a figyelmet a mütét előtti stresszoldás fontosságára. További betegfüggő faktor az obesitas, a megelőző fájdalmas mütét vagy a mütétet megelózó fájdalom. További faktorok az életkor, a nem és a genetikai tényezôk [40].

A mútéti beavatkozástól függően a posztoperatív fájdalmak nagy része neuropátiás, illetve a neuropátiás komponens gyakran sokkal súlyosabb, mint a nociceptiv fájdalom. Ezt a kategóriát tudjuk befolyásolni a leginkább a megfelelően választott perioperatív anesztéziai módszer és technika alkalmazásával, a posztoperatív fájdalmakban szenvedő betegek arányának csökkentése és a kialakult krónikus neuropátiás panaszok enyhítése érdekében.

\section{A mútét utáni krónikus fájdalom kialakulásának molekuláris és celluláris háttere}

Szövetsérülés esetén az egyébként nyugalomban lévő elsődleges érzőneuronok aktivizálódnak, melyeknek fájdalomingerek - mechanikai, hő, illetve kémiai - felfogására specializálódott idegvégződései a nociceptorok. A nem mielinizált C-rostok és a vékony mielinhüvellyel rendelkező A $\delta$-rostok közvetítik a fájdalomérzetet kiváltó stimulusokat a hátsó gyöki ganglionba és a gerincvelői hátsó szarvba. Szövetkárosító ingerek hatására a felszabaduló mediátor anyagok a specifikus farmakológiai receptorokat aktiválják, vagy érzékenyítik a receptorokat, facilitálják a jelátírási folyamatot. A folyamatban részt vesznek aminok (hisztamin, szerotonin), kininek (bradikinin), lipidek (arachidonsav-származékok, prosztaglandin-E2, prosztaglandin-I1, tromboxán-A2), citokinek (interleukin-1), protonok (H, K), ATP, direkt bö- és mechanikai hatás, primer afferens peptidek (CGRP - kalcitonin gén-rokon peptid; sP - P-anyag), proteinázok (trombin, tripszin). Sorozatos vagy hosszan tartó szöveti ingerek hatására a „silent” (nyugvó) receptorok is érzékennyé válnak, a receptív mező területe nő, a periféria túlérzékenyítődik, perifériás szenzitizáció alakul ki. A gerincvelői hátsó szarvban, a substantia gelatinosában végződő primer afferensek az interneuronokat és a széles dinamikus tartományú (wide dynamic range - WDR) idegsejteket érzékenyítik: a kisülések frekvenciája fokozódik, a gerincvelői ingerülettovábbítás felpörög („windup"), a gerincvelő már nemcsak a szövetkárosító, de az ártalmatlan ingerekre is érzékennyé válik, centrális szenzitizáció alakul ki. Ebben a folyamatban is számos receptor, például NMDA (N-metil-D-aszparaginsav), AMPA (amino-metil-propánsav) és sokféle mediátor anyag, például CGRP, sP, szomatosztatin vesz részt. A krónikus fájdalom kialakulásáért a centrális szenzitizáció felelős, melyet helyi érzéstelenítővel végzett perifériás idegblokáddal (PIB) tudunk megelőzni. A perifériás szövetek, a perifériás nociceptorok, továbbá a DRG és az egész idegrendszer túlérzékenyítetté válik a beérkező, egészen enyhe szenzoros információkra is, továbbá jelentős spontán elektromos aktivitást mutatnak. A plaszticitás az idegrendszer képessége, hogy a tapasztalatokból tanuljon, és aktivitásfüggő módon a környezeti változásokhoz adaptálódjon. A neuroplaszticitás anatómiai és funkcionális változások sora, mely molekuláris és szinaptikus kapcsolatokon is érvényesül, végeredményben valódi neuroanatómiai reorganizációt eredményez a gerincvelői és a felsőbb szintű idegrendszeri területeken.

Altatott betegnél a nociceptiv információ bejut a gerincvelői hátsó szarvba, majd a magasabb idegrendszeri struktúrákba. A később fájdalomként értékelt nociceptiv stimulus a szenzoros-diszkriminatív (anterolateralis köteg) és az affektív-motivációs (dorsalis köteg) komponens továbbításáért felelős pályákon keresztül kerül a 
magasabb agyi központokba, ott stressz- és modulációs folyamatokat elindítva. A stresszreakció szimpatikus idegrendszeri tónusfokozódást idéz elő (például vasoconstrictio, vérnyomás-, pulzusszám-, légzésszám-, légzésivolumen-emelkedés, verejtékezés, könnyezés, a zsigeri vérátáramlás csökkenése stb.), mely több órán keresztül komoly neuroendokrin, metabolikus, immunológiai és hematológiai változásokat indít. A modulációs folyamat lehet fájdalomerősítő vagy fájdalomelnyomó rendszer, fokozhatja vagy csökkentheti a fájdalomérzékelést, mely lehet rövid idejü folyamat - ,short-term facilitation" (STF) és ,short-term depression” (STD) - vagy hosszú idejü változás, azaz „long-term potentiation”(LTP) és „longterm depression” (LTD). Mindezek rontják a gyógyulási folyamatot, megnövelik a lábadozási periódust, negatív kihatással vannak az alapbetegségre, emelik a komorbiditás rizikóját, a cardio- és cerebrovascularis események kockázatát, fokozzák a thrombemboliás kórképek és a bronchopneumonia incidenciáját.

\section{A regionális érzéstelenítés újabb reneszánsza}

A regionális érzéstelenítésben végzett mütétek nagy részénél már korábban szembetûnő volt, hogy a betegeknél - a RA más előnyös tulajdonságai és hatásai mellett - kisebb intenzitású posztoperatív fájdalom jelentkezett, így az aneszteziológusok egy része ragaszkodott a RAtechnikákhoz, és továbbra is használta azokat - önálló módszerként vagy a GA mellé kombinációban, illetve a mütétet követően alkalmazva - a mütéti vagy a mütét utáni fájdalmak csökkentésére. Az 1990-es években megjelent idegstimulátor-technika némi hatással volt a RA-k számának emelkedésére, mellyel nagyobb találati arányt sikerült elérni, de használata kissé körülményesebb, és a beteg számára is kellemetlenséget okozó hatása miatt nem vált igazán népszerűvé. Ez a technika is biztos anatómiai ismereteket és kellő tapasztalatot feltételez, ám ezek birtokában is „vakon végzett” technika, mivel indirekt jelek alapján dől el, hogy a túhegy megfelelő közelségben van-e az érzésteleníteni kívánt idegképlethez. Ez a technika sem respektálta az anatómiai variációkat, sőt alkalmanként fals negatív - a tühegy az idegképlet mellett van, de stimulációra nincs optimális válasz - vagy fals pozitív - a túhegy távol van az idegtől, mégis pozitív választ kapunk - eredményt hozott. A találati valószínüség a szabadkézi technikákhoz képest emelkedett, de a sikerarány még magas volumenú idegblokádoknál is messze elmaradt a kívánatostól, mivel nem segítette a variációk felkutatását és az idegek vizualizációját. Szabadkézi blokádoknál a 70-90\%-os sikerarány jónak mondható, de akinél nem sikerül, az adott betegnél a RA sikertelensége teljes - a statisztika egy konkrét betegre nem alkalmazható. Az UH-készülékek megjelenése az anesztéziában forradalmasította a RA-t; kiderült, hogy a sikertelenségek legnagyobb százalékáért az egyébként igen gyakori anatómiai variációk a felelősek, melyeket nem ismerhetünk fel vizuális kontroll nélkül. Az UH alkalmazása lehetővé tette az anatómiai képletek - ideg- és érstruktúrák, egyéb viszonyítási pontok - vizualizációját, elősegítette, hogy a gyógyszeradagolás pontosan a kívánt helyre történjen, és megkönnyítette a variációk felismerését, ami a sikerarány jelentős javulásához vezetett. A RA és a posztoperatív fájdalomcsillapítás öszszefüggésének koncepciója teret nyert a mindennapokban, a PIB-okat tudatosan kezdték alkalmazni a műtét utáni fájdalmak csökkentésére és kivédésére. Az előnyös hatások és a kedvező megfigyelések hatására az 1998-tól elindult fájdalomcsillapítás multimodális megközelítésének koncepciója a mútéti fájdalomcsillapításban is teret nyert. A mütét utáni fájdalmak krónikussá válásának tendenciáját jelentős mértékben sikerült megfékezni az alkalmazott RA-technikákkal, ez vezetett annak felismeréséhez, hogy a mútét utáni krónikus fájdalmak megelőzhetók, így a preventív analgesia fogalma a 2010-es évek második felében széles körben elterjedt.
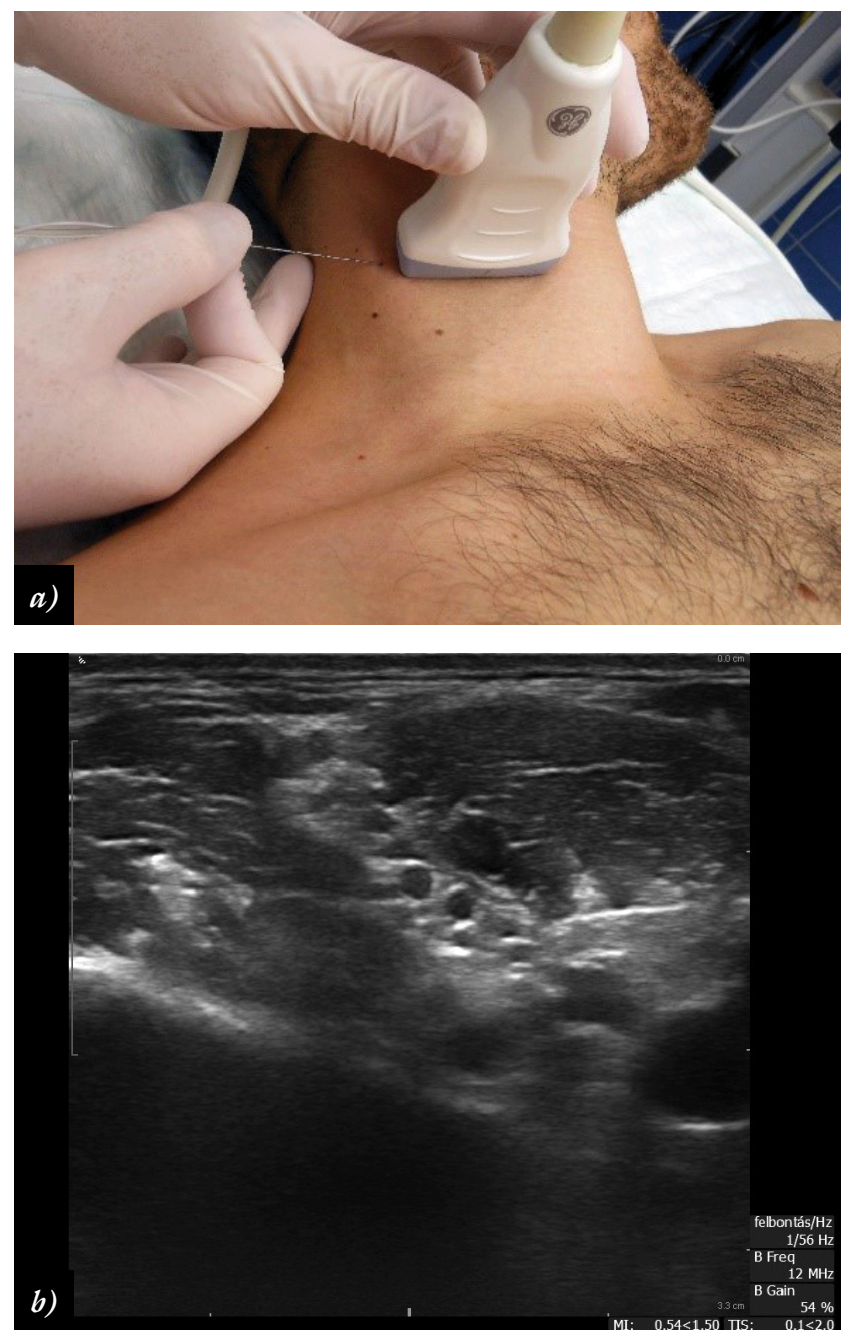

1. ábra a) Vizualizáció és az idegblokád kivitelezése UH segítségével b) A képernyőn megjelenő idegképlet (plexus brachialis)

$\mathrm{UH}=$ ultrahang 


\section{Az ultrahang alkalmazása az anesztéziában - biotechnikai előrelépés}

Az ultrahang első orvosi használatára 1942-ben került sor, Dussik osztrák neurológus a szerkezetével agytumorokat vizsgált. 1948-ban Ludwig epekövet és idegen testet mutatott ki, 1958-ban Donald elsóként szülészeti és nőgyógyászati UH-vizsgálatot végzett. 1989-ben Lichtenstein a közismert megállapítást tette: „az ultrahang az igazi sztetoszkóp”. Az anesztéziában Kapral 1994-ben írta le az UH használatát a karfonat blokádjára [12], majd munkatársa, Marhofer 2010-ben már 15 éves tapasztalatról számolt be [41]. Látható, hogy az UH orvosi alkalmazásának története egészen új. A medicinában, különösen a mütétes szakmákban és az aneszteziológiában az ugrásszerü technikai és informatikai innováció megköveteli a szakorvosoktól a korszerü technikák használatának elsajátítását és az innovatív gondolkodást. $\mathrm{Az} \mathrm{UH}$ használata ma is vizsgálófüggő, ezért a hang fizikájának megértése és az UH fejlődésének megismerése a gyakorlattal és tapasztalatszerzéssel együtt segít az orvostudomány jelen állásának megfelelő diagnosztikai és terápiás készségek kialakításában $[42,43]$.
Az UH-készülék az emberi füllel nem hallható hangokat - feldolgozás és jelátalakítás után - képi információként jeleníti meg. Az UH anesztéziai használata semmi többet nem jelent, mint vizualizációt. Ám az a tény, hogy egy kifinomult technikával képesek vagyunk bőrfelszín alatti struktúrák vizsgálatára, kifejezetten elősegítette az idegképletek tanulmányozását, az idegelemek erekhez és más viszonyítási pontokhoz való viszonyának értékelését. A vizsgálófej, a tű és a célzott struktúra egymáshoz való viszonylatai döntően meghatározzák az alkalmazott technikát, a szúrás irányát, szögét, a használni kívánt tü hosszát, minőségét, s ezek nemcsak a testtájak szerint, de ugyanabban a régióban betegenként is különböznek (1. ábra).

A modern, multimodális megközelítés részeként alkalmazott PIB-ok célja a fájdalomkeltő, nociceptiv ingerek gerincvelőbe és magasabb idegrendszeri struktúrákba jutásának megakadályozása (2. ábra). Ezt a célt nagy találati pontossággal, helyi érzéstelenítőoldat adagolásával végzett idegblokádokkal érhetjük el. Jó minőségű regionális érzéstelenítéssel csökkenthető az opioidszükséglet, az általános érzéstelenítés mellékhatásainak és szövődményeinek kockázata.

Fájdalompercepció
Corticalis erősítés
Kognitív viselkedésterápia
Placebo
Motoroskéreg-stimuláció
Opioidok
a2-AR-agonisták

Leszálló moduláciô

Antidepresszánsok Opioidok, tramadol a2-AR-agonisták Izomrelaxánsok Kannabinoidok Akupunktúra

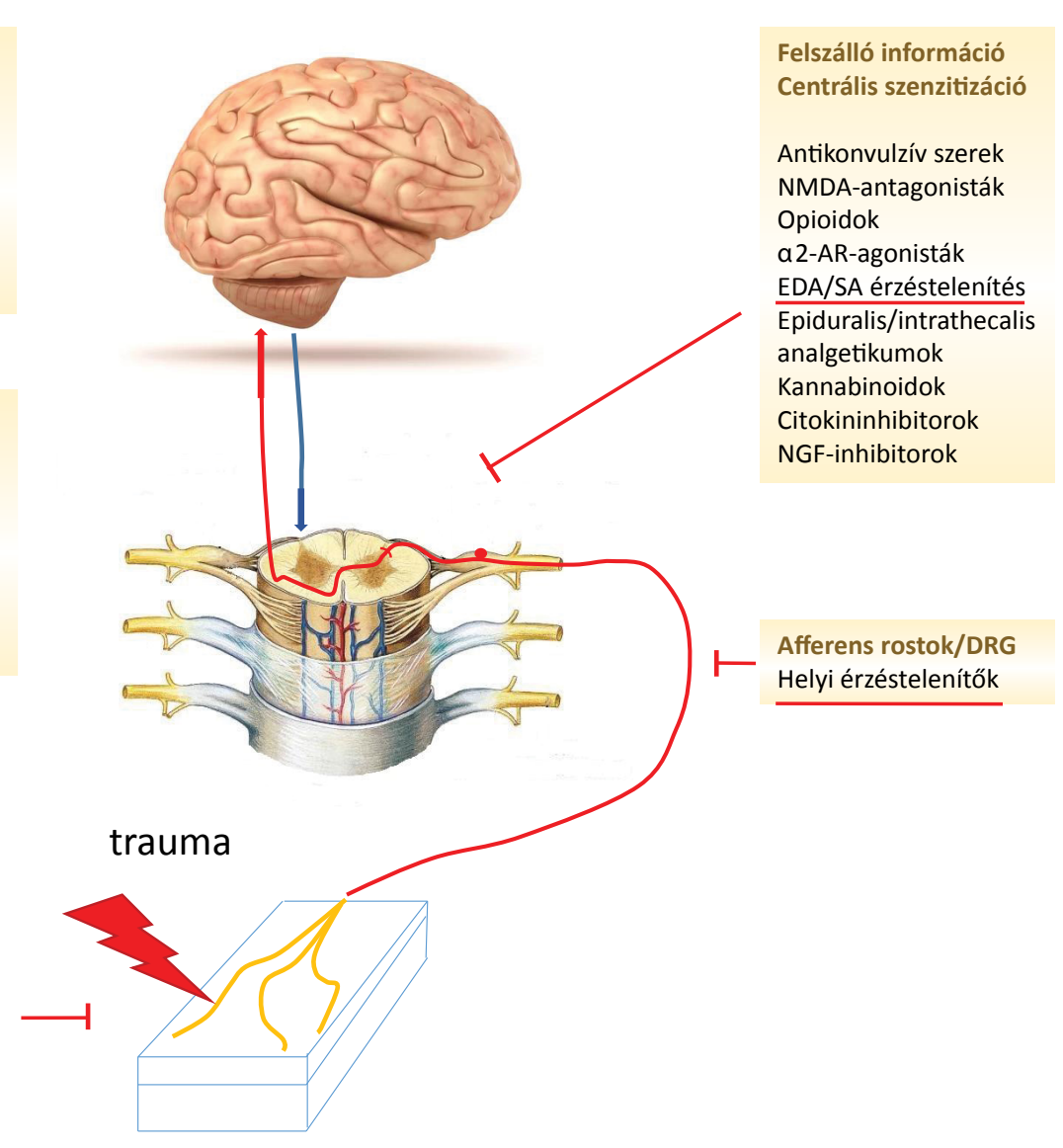

Periféria/nociceptorok Helyi érzéstelenítők gyulladáscsökkentők

\footnotetext{
A nociceptio-fájdalompercepció folyamatában az afferens információáramlás megszakítható a stimulus helyén, az elsődleges érzőneuronokban az érzőidegek blokádjával, a gerincvelói hátsó szarvba befutó ingerületek blokkolásával és a felszálló információ blokádjával helyi érzéstelenítők alkalmazásával

$\alpha 2-\mathrm{AR}=$ alfa-2-adrenerg receptor; DRG = hátsó gyöki ganglion; EDA = epiduralis érzéstelenítés; NGF = idegi növekedési faktor; NMDA = N-metilD-aszparaginsav; $\mathrm{SA}=$ spinalis érzéstelenítés
} 
A PIB relatív sikertelenségének oka az anatómiai variációkban található. Ismeretes - amióta UH segítségével végezzük blokádjainkat -, hogy a variációk lehetősége nagy, különösen a karfonat törzsei, kötegei és idegei esetében, de még a viszonylag standard anatómiai lefutást követő lágyéki és keresztcsonti fonat esetében is. A variációk között előfordul számfeletti vagy a vártnál kevesebb idegelem, izomban futó, az érképlet mellett szokatlan elrendeződést mutató idegstruktúra vagy más anatómiai nehezítettség, például elhízás, a scalenus izmok variációja, rövid nyak vagy diszlokációt okozó térfoglalás, például struma, vérömleny, vagy csak egyszerüen nem férünk hozzá az adott testtájhoz, például inveterált felkartörés miatt nem mozdítható vállöv, begipszelt végtag. Az UH alkalmazása a koncepciójában teljesen új lehetőséget enged, ugyanis láthatóvá teszi az idegelemeket és az egyéb, tájékozódásra szolgáló anatómiai képleteket, a tüt, a túhegyet és a helyi érzéstelenítőoldat terjedését, ezáltal a PIB technikai kivitelezését pontosítja, javítja.

\section{A perifériás idegblokádok technikai minőségének javulása}

Még egy 2009-es összefoglaló tanulmány szerint az UH használatával kevesebb a ráfordított idő és a próbálkozások száma, jelentősen javult az érzéstelenítések minősége, viszont az elért magas hatékonyság (95-100\%) nem különbözött jelentősen más technikákhoz képest. Az UH-technika előnyei között leírták, hogy nem volt komoly, publikált mellékhatás. Az akkori evidenciák nem sugallták, hogy az UH javítaná a sikerarányt más technikákhoz viszonyítva, hatékonyságát tekintve nem találták rosszabbnak, a kockázatokat viszont nem fokozza, és más betegközpontú előnyöket is kínált. Az UH használata önállóan csökkenti a beavatkozás idejét, azonban idegingerlővel együtt növeli, így több beteg igényel kiegészítő anxiolyticus gyógyszerelést. Az idegingerléssel együtt végzett UH-használat esetén a hatásbeállás gyorsabb tendenciát mutat magasabb sikeraránnyal, de nincs kimutatható statisztikai különbség. Az Amerikai Regio- nális Anesztézia Társaság 2010-es összefoglalója szerint az UH javította az idegblokád tulajdonságait, ami főleg a beavatkozást végző személy érdeme, de tartózkodott betegbiztonsági evidenciák említésétôl, mivel nem volt demonstrált javulás a komoly komplikációk tekintetében. Egy 2013-ban, alig három évvel később megjelent összefoglaló tanulmány szerint a javuló biztonság az UH-irányításnak köszönhető. Az áttekintés szerint az UH-irányítással tizedrészére csökkent a helyi érzéstelenítô okozta szisztémás toxicitás (local anaesthetic systemic toxicity - LAST), mivel a jó vizualizálhatóság miatt a tứhegyet az idegstruktúra közelébe lehet vezetni, emiatt annak közvetlen környezetébe adható a helyi érzéstelenítő, melynek dózisa a tradicionális $40 \mathrm{ml}$ körüli volumenről akár 5-15 ml-re csökkenthető. Valószínúleg a dóziscsökkentés következménye a kimutatható tendencia, hogy kevesebb a hosszan tartó neuropátia. Az UH nyilvánvalóan jobb más technikákhoz képest, fóként, ha az elérendő célunk a maximális hatékonyság és a legkisebb rizikó [44] (1. táblázat).

A nyilvánvaló tények (például az idegképlet, a tú vagy túhegy, a környező anatómiai struktúrák, a LA-terjedés láthatósága) mellett számos tanulmány talált bizonyító erejű adatokat az UH használatának előnyeire: gyorsítja a beavatkozást, javul az anesztézia minősége (szenzoros és motoros blokád), csökken a kiegészítő gyógyszerelés, kisebb a minor szövődmények aránya. A bizonyítékok egybevágóak: az UH használata csökkenti az érsérülést, a szisztémás toxicitást, a pneumothoraxot és a nervus (n.) phrenicus véletlen blokádját. A rövid ideig tartó idegsérülés incidenciája egyértelmúen csökken az idegstimulátor-technikához képest. Az UH alkalmazása új idegblokádok kifejlesztéséhez vezetett (például pectoralis - PECS-I, PECS-II vagy quadratus lumborum - QL), finomította az eddig használatosakat (például transversus abdominis plane - TAP, felső és alsó végtagi idegblokádok), vagy új, biztonságosabb megközelítéseket eredményezett (például koaxiális blokádok, paravertebralis idegblokádok).

Fontos hangsúlyoznunk, hogy a betegek biztonsága nem csak egy technológiai tényezótól függ! A betegbiz-

1. táblázat $\mid A z U H$ használatának technikai előnyei

\begin{tabular}{ll}
\hline Vizualizálhatóság & Láthatóságból eredő elónyök \\
\hline Látható a tű, a tưhegy és a tű mozgásai. & Minimalizálható a véletlen érpunkció. \\
\hline Nyomon követhető a LA terjedése. & Csökken a LAST incidenciája. \\
\hline Az idegstruktúrák, az érképletek láthatóvá válnak. & Minimalizálható az intraneuralis adagolás. \\
\hline Kompresszióval azonosíthatók az artériák, vénák. & A neurológiai szövődmények incidenciája csökkenthető. \\
\hline Színes Doppler segítségével az erekben áramlás azonosítható. & Csökkenthető az ismételt szúrások száma. \\
\hline Differenciálhatók az ideg- és érképletek, az ín- és érképletek. & Javul a sikerarány. \\
\hline Valóságos idejű módszer. & Gyorsabb a beállási idő. \\
\hline Csökken a beavatkozásra fordított idő. & Csökkenthető az alkalmazott helyi érzéstelenítő dózisa.
\end{tabular}

LA = helyi érzéstelenítő; LAST = helyi érzéstelenítő szisztémás toxicitása; UH = ultrahang 
tonság a jól képzett aneszteziológusra támaszkodik, aki különös figyelmet fordít az indikációra, a megfelelő betegválasztásra, az anatómiára, a gyógyszertani ismeretekre, a készülékismeretekre és az idegblokád kivitelezésének technikájára, továbbá a nem technikai képességekre, mint a kommunikáció és a szituációs találékonyság [45].

\section{A perifériás idegblokádok biológiai és élettani hatásai}

Míg a perifériás idegblokádok biztonságos technikai kivitelezésére világszerte igen nagy gondot fordítanak, sajnálatosan kevés figyelem esik a posztoperatív fájdalom és az egyéb, a betegek életminőségét döntően befolyásoló faktorok és a regionális érzéstelenítés kapcsolatának tanulmányozására. A sebészi beavatkozásokból eredő fájdalmak kezdetben szövetkárosító traumákból erednek, de ezek következménye a fizikai, a kognitív és az emocionális diszkomfort. A posztoperatív és krónikus, mütét utáni fájdalmakkal foglalkozó tanulmányok egyértelmúvé teszik az UH-irányítással végzett idegblokádok szerepét. A szisztémás analgesia kiegészítésére alkalmazott perifériás idegblokád csökkenti a fájdalom intenzitását a csak szisztémásan alkalmazott fájdalomcsillapításhoz képest nagy térdmütétek után [46]. Térdprotézismütét után a femoralis idegblokád (FIB) egyéb kezeléssel (például betegkontrollált opioidanalgesia - PCA) vagy önállóan hatékonyabb fájdalomcsillapítást ért el, mint a PCA önmagában. Minőségében és időbeli kiterjesztésében hasonló, mint az EDA, de kevesebb a hányinger/hányás a PCA-hoz vagy EDA-hoz képest. A folyamatos FIB jobb analgesiát biztosít, mint az egyszeri injekciós technika. A PIB javítja a kimenetelt humerustörés osteosynthesise után. ISC-blokádban érzéstelenített betegek funkcionális kimenetele és a mozgástartomány jobb volt, hosszabb posztoperatív fájdalomcsillapítást eredményezett, koraibb mobilizációt engedett meg, mindezekkel együtt növelte a valószínúségét, hogy a betegek mozgásfunkciói a kiindulási szintre térjenek vissza [47]. Negatívumként természetesen számolnunk kell a kedvezőtlen pszichés mellékhatásokkal (például az éber állapot miatt egyes betegeknél fokozódó stressz vagy a szituáció feldolgozásának zavara miatt kialakuló magatartási, kommunikációs problémák, zavartság), melyek kellő betegválogatással és feszültségcsökkentő premedikációval kivédhetők. Invazív technikáról lévén szó, gondolnunk kell a potenciális érsérülésekből eredő vérzéses szövődményekre, véletlen érbe adásra (LAST), a ritka allergiás reakciókra és a methaemoglobinaemiára is. Különösen a nyaki régióban az érkontaktus vagy -sérülés spazmust okozhat (például arteria vertebralis), mely az ellátási terület keringési zavarával járhat. A célstruktúra közelében található képletek véletlen infiltrációja helyi érzéstelenítôvel Horner-szindrómát (ganglion stellatum blokád), n. laryngeus recurrens blokádot (rekedtség), n. phrenicus blokádot (légzési zavarok, hypoxia; különösen COPD és tüdóbetegségek esetén) okozhat. A mellhártya felé vezetett tưhegy pleurasérülést (pneumothorax), a transforaminalis vagy intraduralis túhegypozíció magas spinalis blokádot idézhet elő. A törzsön vagy az alsó végtagon számolnunk kell a véletlen hashártyasérülés lehetőségével, a kismedencei érképletek és zsigerek potenciális sérülésével, de előfordulhat nem szándékos epiduralis vagy spinalis érzéstelenítés is. UH alkalmazásával és kellő gyakorlattal ezek a szövődmények megelőzhetők. Nem elhanyagolható szempont az aszepszis szabályainak betartása a lehetséges fertőzéses szövődmények kivédése érdekében, különösen a mütéti terület közelében végzett perifériás idegblokádok esetén. Szinte minden PIB esetén kialakul átmeneti neurológiai deficit (TND), mely a legtöbb esetben nem okoz klinikai tüneteket vagy szubjektív panaszokat.

\section{Posztoperatív fájdalomcsillapítás - folyamatoskatéter-technika}

Ha a beteg várhatóan súlyos fájdalmaktól $(7<$ a vizuális numerikus skálán, VNS: 0-10) fog szenvedni mütét után, javasolt folyamatos perineuralis katéter behelyezése még a mútét elött - amennyiben a beavatkozás azt lehetővé teszi. Folyamatos plexus brachialis blokád preferált minden vállmütét utáni fájdalomcsillapításhoz. Ezek alapján új trend indult a vállsebészeti RA-ban a betegek életminőségét súlyosan rontó mellékhatások elkerülésére, melynek alapja a mútéttel kapcsolatos nociceptiv ingerek útjának megszakítása. Ma már a PIB bizonyítottan a legfóbb fegyver a posztoperatív multimodális fájdalomcsillapitás arzenáljában [48, 49]. A közepes és súlyos fájdalmak csillapítása évszázadok óta - mind a mai napig - opioidalapú. A hatékony fájdalomcsillapítás ára a kedvezőtlen mellékhatásprofil, légzésdepresszió, megváltozott tudatállapot, szedáció, székrekedés, tolerancia, dependencia és potenciális addikció. Az opioidok továbbá hyperalgesiát váltanak ki, és kedvezőtlen hatást gyakorolnak a tumornövekedésre és -recidívára. Nyilvánvaló igény merül fel egy opioidoktól független fájdalomcsillapítási stratégiára akár a multimodális fájdalomcsillapítás részeként, akár önállóan, melyben a perifériásideg-katéterek és a helyi folyamatos infiltrációs technikák értékes opciót jelenthetnek (3. ábra). A folyamatos idegkatéterek előnyei abban rejlenek, hogy napokra (hetekre) kitolható, kitűnő fájdalomcsillapítást eredményeznek az opioidok és nemszteroid gyulladáscsökkentők kockázatos mellékhatásai nélkül. Használatuk ma egyre gyakoribb, mivel alkalmasak lehetnek a beteg és az ápolószemélyzet számára is olykor nyügös PCA-rendszerek leváltására - például a pumpa riaszt, a fecskendőt tölteni kell, a beteget oktatni kell a szükséges használatról, áramforrásigénye van, a beteg nehézkesen hagyja el az ágyat a pumpával. Egy perineuralis katéterre csatlakoztatható elasztomerikus pumpa új alternatíva lehet, mivel koncepciója szerint helyi érzéstelenítőoldatot használ, az afferentatiót a központi idegrendszer felé megszakítja, nem engedi a centrális szenzitizáció és a stresszreakció 
Preventív analgesiatechnikák

Preoperatív folyamatos PIB perineuralis kanül

- preop. foly. EDA, TPVB

- preop. foly. PIB ismételt bolusok

- preop. PIB egyszeri „nagy” dózis, TPVB

- preop. PIB egyszeri „kis” dózis „trend”

- folyamatos opioid PCA + NSAID

- folyamatos opioid, PCA

Preemptív opioid

- preemptív NSAID, a2-RA, NMDA-RAnt

Posztoperatív PIB, kombinált gyógyszeres fájdalomesillapítás (C-MDT)

- posztop. sebinfiltráció; PCRA

- posztop. opioid, PCA

- posztop. analgesia, NSAID

Nincs fájdalomesillapítás

0\% valószínűség a centrális szenzitizációra

nociceptio blokádja $24 \mathrm{~h}<$

$24 \mathrm{~h}<$

$24 \mathrm{~h}<$

$8-16 \mathrm{~h}$

$3-8 \mathrm{~h}$

mütét alatt folyamatos

nociceptiv stimulusok

de folyamatos

fájdalommoduláció

posztop. nociceptiv blokád

$2-5 \mathrm{~h} ; 24 \mathrm{~h}<$

100\% valószínűség a centrális szenzitizációra

3. ábra

\begin{abstract}
A fájdalomcsillapító módszerek és idóbeli alkalmazásuk hatása a centrális szenzitizációra
DRG = hátsó gyöki ganglion; EDA = epiduralis érzéstelenítés; $\mathrm{MDT}=$ multimodális gyógyszeres kezelés; NSAID = nemszteroid gyulladácsökkentő; PCA = pácienskontrollált analgesia; PCRA = pácienskontrollált regionális érzéstelenítés; PIB = perifériás idegblokád; TPVB = thoracalis paravertebralis blokád
\end{abstract}

kialakulását, nincs szükség a modulációs rendszerek beindítására, és mentes az opioidok használatától. Továbbá teljesen automatikus, 72 óráig adagolja a fix dózisú oldatot, áramigénye nincs, nem csipog, nem kell tölteni, a beteget nem zavarja a mozgásban, a nővéri időráfordítás elhanyagolható, az ápolás könnyü; a panaszmentes beteg hangulata és életminősége a kórházi tartózkodással járó minimális diszkomfort mellett is jó (4. ábra).

$\mathrm{Az}$ anesztézia és a fájdalomcsillapítási technika választása nem egyszerúen csak az anesztézia minőségét befolyásolja. A RA és a GA gyakran kerül összehasonlításba a stresszválaszcsökkentés vagy a tumornövekedés elősegítésének szempontjából. A RA-nak számottevő előnyei vannak a kortizol- és a katecholaminszintek csökkentésében, így az izomtömeg posztoperatív lebontásának re-

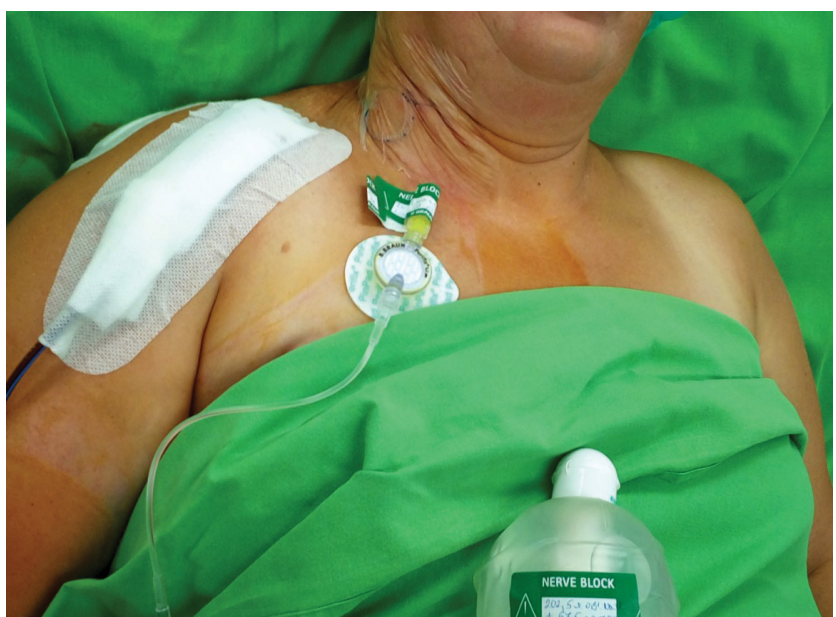

4. ábra

A felső végtag fájdalomcsillapítására alkalmazott, perineuralis katéterre csatlakoztatott elasztomerikus gyógyszeradagoló pumpa dukálásában. Jóval kisebb immunszuppresszív hatással bír, így jelentôsen redukálja a proinflammatiós citokinek termelését. Ily módon a RA alkalmasabb az életfontos szervek, az agy- vagy a vesefunkciók védelmére. A párolgó anesztetikumok - összehasonlítva a RA-val vagy az intravénás anesztetikumokkal -, úgy túnik, elnyomják a nemspecifikus immunválasz effektorsejtjei közé tartozó natural killer (NK) sejtek aktivitását, ezzel elősegítik a malignus folyamatok progresszióját, és csökkentik a szervezet ellenálló képességét a tumorsejtekkel szemben [42]. A posztoperatív kimenetel összetett, sok változótól függő modell, melyet többváltozós logisztikai regressziós módszerrel lehet vizsgálni. Az eredményváltozók között lehet szív-ér rendszeri, pulmonalis, gastrointestinalis, renalis szövődmény, cerebrovascularis esemény, sebgyógyulási zavar, thrombemboliás szövődmény, kórházi elesés és halálozás is. Magyarázó változó a GA és RA mellett még sokféle lehet: például transzfúzió, intenzív osztályos felvétel, opioidfogyasztás, NSAID-fogyasztás, kórházi napok száma. Térdprotézismútéten átesett betegeknél vizsgálták a kimenetelt; a PIB használata esetén a legtöbb kedvezőtlen mellékhatás incidenciája jelentôsen alacsonyabbnak bizonyult: a sebgyógyulás kedvezőbb, a légzési szövődmények száma kisebb lett, az opioidfogyasztás csökkent. A RA hatása valószínúleg egyéb mútétes populációban is kedvező a kimenetelre, aminek igazolását a jövőben multicentrikus, randomizált vizsgálatoktól várjuk [50].

\section{Megbeszélés}

A ma már egyre növekvő számban mütét előtt is alkalmazott perifériás idegblokád bizonyítottan hatékony eszköz a krónikus posztoperatív fájdalom megelőzésére. Az 
UH-irányítással végzett idegblokád elkerüli a GA rizikóit (laringoszkópia, légútbiztosítás, mesterséges eszméletlenség, sphinctertónus-csökkenés, lélegeztetés, opioidhasználat, neuromuscularis blokád, hemodinamikai változások) és potenciális mellékhatásait (aspiráció, malignus hipertermia, hipotenzió, hipo- és hiperventiláció, agyi keringészavar, szedáció, izomgyengeség, légzészavar, posztoperatív kognitív diszfunkció [PKD]). A PKD a mưtét után megjelenő új kognitív funkcionális eltérés, mely az idősebb korosztályt érinti a leginkább, és a rövid távú emlékezés, bevésés és memóriafelidézés, a koncentráció, a figyelem és a feladatmegoldási készség zavara jellemzi. A PIB az afferentatio blokkolásával megelőzi a centrális szenzitizációt, emiatt koncepcionálisan az elérhető leghatékonyabb fájdalomcsillapítás az intra- és posztoperatív időszakban. A posztoperatív fájdalomkontroll kitolható órákra, meghosszabbítható napokra, különösen a perineuraliskatéter-technika alkalmazásával. Így az opioid-mellékhatások elkerülhetők (légzésdepresszió, szedáció, hányinger, hányás, obstipáció), és megelőzhetők az opioidhasználat egyéb potenciális szövődményei (opioidindukált hyperalgesia és a tumornövekedésre gyakorolt kedvezőtlen hatás). Ultrahang-irányítással nemcsak mútéti érzéstelenítés, de hosszan tartó fájdalomcsillapítás is végezhető, mely egyéb betegcentrikus előnyökkel, különösen a kimenetel és az életminőség javulásával is jár - ezek elérése a gazdasági tényezők mellett betegeink érdekét célozza.

Anyagi támogatás: A közlemény megírása anyagi támogatásban nem részesült.

A szerző a cikk végleges változatát elolvasta és jóváhagyta.

Érdekeltségek: A szerzőnek nincsenek érdekeltségei.

\section{Irodalom}

[1] Lawrie E. Death during anaesthesia. BMJ 1892; 1(1630): 651652.

[2] Gaedcke, F. Ueber das Erythroxylin, dargestellt aus den Blättern des in Südamerika cultivirten Strauches Erythroxylon Coca Lam. Arch Pharm. 1855; 132: 141-150.

[3] Koller C. Vorläufige Mittheilung über locale Anästhesierung am Auge. Klin Mbl Augenheilk. 1884; 22: 60-63.

[4] Corning JL. Spinal anaesthesia and local medication of the cord. NY Med J. 1885; 42: 483-485.

[5] Looseley A. Corning and cocaine: the advent of spinal anaesthesia. Grand Rounds 2009; 9: L1-L4.

[6] Halsted WS. Practical comments on the use and abuse of cocaine; suggested by invariably successful employment in more than a thousand minor surgical operations. NY Med J. 1885; 42 : 294-295.

[7] Kulenkampff D. Anesthesia of the brachial plexus. [Die Anästhesierung des Plexus brachialis.] Zentralb Chir. 1911; 38: 1337-1340. [German]

[8] Hirschel G. Anesthesia of the brachial plexus for operations on the upper extremity. [Die Anästhesierung des Plexus brachialis bei Operationen an der oberen Extremität.] Munch Med Wochenschr. 1911; 58: 1555-1556. [German]

[9] Winnie AP. Interscalenic brachial plexus block. Anesth Analg. 1970; 49: 455-466.

[10] Almási R, Böhm T, Faluhelyi N. (eds.) The use of the ultrasound in anaesthesiology and intensive care. $\mathrm{Az} \mathrm{UH}$ használata az aneszteziológiában és az intenziv terápiában.] Medicina Könyvkiadó, Budapest, 2018. [Hungarian]

[11] Ting PL, Sivagnanaratnam V. Ultrasonographic study of the spread of local anaesthetic during axillary brachial plexus block. Br J Anaesth. 1989; 63: 326-329.

[12] Kapral S, Krafft P, Eibenberger K, et al. Ultrasound-guided supraclavicular approach for regional anesthesia of the brachial plexus. Anesth Analg. 1994; 78: 507-513.

[13] Széll K. The role of regional anaesthesia in contemporary anaesthesiology. [A regionalis érzéstelenítés helye a korszerú anaesthesiológiában.] Orv Hetil. 1982; 123: 1651-1658. [Hungarian]

[14] Chopra V, Bovill JG, Spierdijk J. Accidents, near accidents and complications during anaesthesia. A retrospective analysis of a 10-year period in a teaching hospital. Anaesthesia 1990; 45: 3-6.

[15] Moayedi M, Davis KD. Theories of pain: from specificity to gate control. J Neurophysiol. 2013; 109: 5-12.

[16] Melzack R, Wall PD. Pain mechanisms: a new theory. Science 1965; 150: 971-979.

[17] Melzack R. The gate control theory 25 years later: new perspectives on phantom limb pain. In: Bond MR, Charlton JE, Woolf CJ. (eds.) Proceedings of the VIth World Congress on Pain. Elsevier, New York, NY, 1991; pp. 9-26.

[18] Melzack R. Pain and stress: a new perspective. In: Gatchel RJ, Turk DC. (eds.) Psychosocial factors in pain: critical perspectives. Guilford Press, New York, NY, 1999; pp. 89-106.

[19] Mendell LM. Constructing and deconstructing the gate theory of pain. Pain 2014; 155: 210-216.

[20] Kissin I. Preemptive analgesia: Terminology and clinical relevance. Anesth Analg. 1994; 79: 809-810.

[21] Kehlet H. Multimodal approach to control postoperative pathophysiology and rehabilitation. Br J Anaesth. 1997; 78: 606-617.

[22] Gatchel RJ, Turk DC. (eds.) Psychological approaches to pain management: a practitioner's handbook. Guilford Press, New York, NY, 1996.

[23] Gatchel RJ. Perspectives on pain: a historical overview. In: Gatchel RJ, Turk DC. (eds.) Psychosocial factors in pain: critical perspectives. Guilford Press, New York, NY, 1999; pp. 3-17.

[24] Turk DC, Monarch ES. Biopsychosocial perspective on chronic pain. In: Turk DC, Gatchel RJ. (eds.) Psychological approaches to pain management: a practitioner's handbook. 2nd edn. Guilford Press, New York, NY, 2002.

[25] Pogatzki-Zahn EM, Zahn PK. From preemptive to preventive analgesia. Curr Opin Anaesthesiol. 2006; 19: 551-555.

[26] Vadivelu N, Mitra S, Schermer E, et al. Preventive analgesia for postoperative pain control: a broader concept. Local Reg Anesth. 2014; 7: 17-22.

[27] Dahl JB, Kehlet H. Preventiv analgesia. Curr Opin Anaesthesiol. 2011; 24: 331-338.

[28] Stenberg G, Stålnacke BM, Enthoven P. Implementing multimodal pain rehabilitation in primary care - a health care professional perspective. Disabil Rehabil. 2017; 39: 2173-2181.

[29] Wick EC, Grant MC, Wu CL. Postoperative multimodal analgesia pain management with nonopioid analgesics and techniques. A review. JAMA Surg. 2017; 152: 691-697.

[30] Wardhan R, Chelly J. Recent advances in acute pain management: understanding the mechanisms of acute pain, the prescription of opioids, and the role of multimodal pain therapy. F1000 Res. 2017; 6: 2065.

[31] Lavand'homme P. Perioperative pain. Curr Opin Anaesthesiol. 2006; 19: 556-561.

[32] Kehlet H, Wilmore DW. Multimodal strategies to improve surgical outcome. Am J Surg. 2002; 183: 630-641. 
[33] Kehlet H, Jensen TS, Woolf CJ. Persistent postsurgical pain: risk factors and prevention. Lancet 2006; 367: 1618-1625.

[34] Correll D. Chronic postoperative pain: recent findings in understanding and management. F1000 Res. 2017; 6: 1054.

[35] Fletcher D, Stamer UM, Pogatzki-Zahn E, et al. Chronic postsurgical pain in Europe: an observational study. Eur J Anaesthesiol. 2015; 32: 725-734.

[36] Werner MU, Kongsgaard UE. Defining persistent post-surgical pain: is an update required? Br J Anaesth. 2014; 113: 1-4.

[37] Thapa P, Euasobhon P. Chronic postsurgical pain: current evidence for prevention and management. Korean J Pain 2018; 31: 155-173.

[38] Voscopoulos C, Lema M. When does acute pain become chronic? Br J Anaesth. 2010; 105(Suppl 1): i69-i85.

[39] Bruce J, Quinlan J. Chronic post surgical pain. Rev Pain 2011; 5: 23-29.

[40] Iwasaki M, Edmondson M, Sakamoto A, et al. Anesthesia, surgical stress, and "long-term" outcomes. Acta Anaesthesiol Taiwan 2015; 53: 99-104.

[41] Marhofer P, Harrop-Griffiths W, Kettner SC, et al. Fifteen years of ultrasound guidance in regional anaesthesia. Part $1 . \mathrm{Br} \mathrm{J}$ Anaesth. 2010; 104: 538-546.

[42] Richter P. (ed.) The principles and context of ultrasound imaging. [Az ultrahang-képalkotás alapelemei és összefüggései.] Medicina Könyvkiadó, Budapest, 2013. [Hungarian]

[43] Harkányi Z, Morvay Z. (eds.) How should we examine with ultrasound? 2nd edn. [Hogyan vizsgáljunk ultrahanggal? 2. kiadás.] Medicina Könyvkiadó, Budapest, 2016. [Hungarian]
[44] Jochum D, Iohom G, Bouazis H. Ultrasound guidance, a winwin approach to peripheral nerve blockade. Curr Opin Anaesthesiol. 2013; 26: 600-604.

[45] Bondár A, Szúcs Sz, Iohom G. Thoracic paravertebral blockade. Med Ultrason. 2010; 12: 223-227.

[46] Xu J, Chen XM, Ma CK, et al. Peripheral nerve blocks for postoperative pain after major knee surgery. Cochrane Database Syst Rev. 2014; 12: 10937.

[47] Egol KA, Forman J, Ong C, et al. Regional anesthesia improves outcome in patients undergoing proximal humerus fracture repair. Bull Hosp Jt Dis. 2014; 72: 231-236.

[48] Fredrickson M, Borgeat A. Continuous interscalene block is preferable to the 'shoulder block' for postoperative analgesia following shoulder surgery. Anaesth Intensive Care 2008; 36: 119120.

[49] Merritt CK, Mariano ER, Kaye AD, et al. Peripheral nerve catheters and local anesthetic infiltration in perioperative analgesia. Best Practice Res Clin Anaesthesiol. 2014; 28: 41-57.

[50] Memtsoudis SG, Poeran J, Cozowicz C, et al. The impact of peripheral nerve blocks on perioperative outcome in hip and knee arthroplasty - a population-based study. Pain 2016; 157: 2341-2349.

(Almási Róbert Gyula dr., Pécs, Ifjúság u. 13., 7624 e-mail: almasi.robert@pte.hu)

\section{"Cui dolet meminit." (Cicero) (Akinek fáj valami, az nem felejt.)}

A cikk a Creative Commons Attribution 4.0 International License (https://creativecommons.org/licenses/by/4.0/) feltételei szerint publikált Open Access közlemény, melynek szellemében a cikk bármilyen médiumban szabadon felhasználható, megosztható és újraközölhetö, feltéve, hogy az eredeti szerző és a közlés helye, illetve a CC License linkje és az esetlegesen végrehajtott módositások feltüntetésre kerülnek. (SID_1) 